\title{
Propolis produced in Bulgaria and Mongolia: phenolic compounds and plant origin
}

\author{
V Bankova 1, A Dyulgerov 1, S Popov 1, L Evstatieva 2, \\ L Kuleva 1, O Pureb 3, Z Zamjansan 3 \\ ${ }^{1}$ Bulgarian Academy of Sciences, Institute of Organic Chemistry \\ and Centre of Phytochemistry, 1113 Sofia; \\ 2 Bulgarian Academy of Sciences, Institute of Botany and Botanical Garden, 1113 Sofia, Bulgaria; \\ ${ }^{3}$ Mongolian Academy of Sciences, Institute of Chemistry, Ulan Bator, Mongolia
}

(Received 18 March 1991; accepted 11 July 1991)

\begin{abstract}
Summary - Phenolic composition of Bulgarian and Mongolian propolis and their possible plant sources (the resinous secretions of different tree buds) were investigated by gas chromatographymass spectrometry (GC/MS). The results obtained demonstrate that in both countries propolis is collected mainly from poplars: from Populus nigra and to some extent from $P$ italica in Bulgaria, and from $P$ suaveolens in Mongolia.
\end{abstract}

propolis / poplar bud / phenolics / GC/MS / Populus

\section{INTRODUCTION}

Propolis (bee glue) is a resinous hive product collected by bees. It possesses versatile biological activities - antibacterial, antiviral, fungicidal, antiulcer, immunostimulating, hypotensive, cytostatic, etc (Ghisalberti, 1979). Recently propolis has been successfully applied in medicine and cosmetics (Lejeune et al, 1984; Pochinkova, 1986) and this fact has stimulated an increasing interest in its chemical composition and origin. Its chemical composition appears to be very complex - at least 156 propolis constituents have been identified so far (Walker and Crane, 1987). The phenolic compounds of propolis constitute more than $50 \%$ of its total weight (Ivanov, 1987) and are probably connected with a substantial part of its biological activity (Ghisalberti, 1979).

It is now generally accepted that bees collect propolis from resinous tree buds, but only a few authors have discussed plant sources in particular geographical regions. Qualitative comparison of the flavonoid aglycones in propolis and bud secretions of different tree species has indicated that in the European part of Russia propolis has been collected mainly from Betula verrucosa bud secretions (Popravko, 1976), in the Ukraine - from Betula verrucosa, Populus nigra and $P$ tremula bud secretions (Popravko and Sokolov, 1980), in France (Lavie, 1976), Great Brit- 
ain (Greenaway et al, 1987), Hungary (Papay et al, 1986), and even in the Sonoran Desert, Mexico (Wollenweber et al, 1987) - from poplar bud secretions. More chemical evidence is needed regarding reports from other parts of the world claiming that propolis can be collected from many other sources (Koenig, 1985). In many areas of the world, especially the Balkans and Asia, almost no information is available on the plant sources of propolis. In this paper we summarize our investigations on the phenolic constituents of propolis and some tree bud exudates from Bulgaria and Mongolia, in order to compare the composition of bee glue from 2 different geographic zones and to determine the main sources of propolis in these regions.

\section{MATERIALS AND METHODS}

Bud material of Populus nigra, $P$ italica, $P$ tremula, Betula verrucosa, Aesculus hippocastanum, Salix alba, Fraxinus excelsior, Alnus glutinosa, Prunus padus, Prunus cerasus, was collected from trees near Sofia. Propolis samples were obtained from the region of Sofia in Bulgaria.

Bud material from Populus suaveolens and propolis samples were collected near Ulan Bator, Mongolia.

\section{Isolation of phenolics from tree bud exudates}

Immediately after collection the tree buds $(2 \mathrm{~g})$ were briefly extracted with acetone $(3 \times 20 \mathrm{ml})$ to dissolve the secretions. The solution was evaporated to dryness, the residue dissolved in $\mathrm{MeOH}(10 \mathrm{ml})$, diluted with water $(5 \mathrm{ml})$ and extracted successively with petrol ether (bp 40$\left.60^{\circ} \mathrm{C}\right)(3 \times 15 \mathrm{ml})$ and $\mathrm{Et}_{2} \mathrm{O}(3 \times 15 \mathrm{ml})$. The combined ethyl ether extracts were dried $\left(\mathrm{Na}_{2} \mathrm{SO}_{4}\right)$ and evaporated to yield a brown residue. An aliquot of each extract was investigated by TLC (DC Alufolien Kieselgen $F_{254}$ Merck, mobile phases $\mathrm{CHCl}_{3} /$ EtOAc $(7: 3)$ and n-hexane/acetone (3:1)) and HPLC (the conditions of the HPLC analysis are described by Bankova et al, 1982) and (for $P$ nigra, $P$ italica, $P$ tremula and $P$ suaveolens) by GC/MS after silylation ( $5 \mathrm{mg}$ ethyl ether extract, $0.1 \mathrm{ml} N$, O-bis(trimethylsilyl)trifluoroacetamide (BSTFA) $\left.70^{\circ} \mathrm{C}, 20 \mathrm{~min}\right)$.

\section{Isolation of phenolics from propolis}

Propolis ( $1 \mathrm{~g}$ ), cut into pieces, was extracted with $10 \mathrm{ml}$ boiling $\mathrm{MeOH}$ for $2 \mathrm{~h}$. Water $(2 \mathrm{ml})$ was added to the filtered extract and extracted 3 times with $\mathrm{Et}_{2} \mathrm{O}$. The ethyl ether extract was dried over $\mathrm{Na}_{2} \mathrm{SO}_{4}$ and evaporated to dryness $(0.5 \mathrm{~g}) .5 \mathrm{mg}$ of the residue was dissolved in 0.1 $\mathrm{ml} \mathrm{BSTFA}$, heated for $20 \mathrm{~min}$ at $70^{\circ} \mathrm{C}$ and analysed by GC/MS.

\section{GC/MS analysis}

For GC/MS analysis a $25 \mathrm{~m}$ OV-101 fused silica capillary column was used in a JEOL JGC-20K gas chromatograph directly coupled to a JEOL JMS-D 300 mass spectrometer. The samples were introduced via a metal injector working in a split mode, with helium as the carrier gas, and a temperature of $150-280^{\circ}$ at $3^{\%} / \mathrm{min}$. The mass spectrometer was run in the electron impact mode, the ionization potential was $70 \mathrm{eV}$, ionization current $300 \mu \mathrm{A}$ and the ion source temperature $170^{\circ} \mathrm{C}$.

\section{Identification of the compounds}

The identification of the compounds is shown in table I. Most of them were identified by comparison with authentic samples (RT and mass spectra) while the remaining part was identified by their mass spectral fragmentation.

\section{RESULTS}

In Bulgaria buds from Populus nigra, $P$ italica, $P$ tremula, Betula verrucosa, Aesculus hippocastanum, Alnus glutinosa, Fraxinus 
Table I. Composition of the phenolic compounds of poplar buds and propolis from Bulgaria and Mongolia. The percentage figures refer to the ion current generated by the compound in the mass spectrometer.

\begin{tabular}{|c|c|c|c|c|c|c|}
\hline Compound & $\begin{array}{l}\text { Bulgarian } \\
\text { propolis }\end{array}$ & $\underset{\text { nigra }}{P}$ & $\begin{array}{c}\mathrm{P} \\
\text { italica }\end{array}$ & $\underset{\text { trem }}{P}$ & $\begin{array}{c}\text { Mongolian } \\
\text { propolis }\end{array}$ & $\begin{array}{c}P \\
\text { suav }\end{array}$ \\
\hline \multicolumn{7}{|l|}{ Flavonoids } \\
\hline Pinostrobin $b$ & $t$ & $t$ & - & _ & - & _ \\
\hline Pinostrobin chalcone ${ }^{a}$ & - & - & - & - & 4 & 4 \\
\hline Pinocembrin ${ }^{b}$ & 23 & 25 & 2 & $t$ & 11 & 12 \\
\hline 3,7-Dihydroxy-5-methoxyflavanone $b$ & $\mathrm{t}$ & $t$ & - & - & - & - \\
\hline 2,5-Dihydroxy-7-methoxyflavanone ${ }^{b}$ & $i$ & $t$ & _ & _- & _ & _ \\
\hline Pinobanksin b & 7 & 6 & 3 & _ & _ & _- \\
\hline Pinobanksin-3-O-acetate ${ }^{b}$ & 6 & 6 & 4 & - & 6 & 7 \\
\hline Galangin ${ }^{b}$ & 6 & 4 & $<1$ & $\mathrm{t}$ & 2 & 2 \\
\hline \multicolumn{7}{|l|}{ Derivatives of cinnamic acid } \\
\hline$p$-Coumaric acid b & $<1$ & 1 & $<1$ & 2 & _ & - \\
\hline Dimethoxycinnamic acid a & $<1$ & $<1$ & 9 & - & _ & - \\
\hline Isoferulic acid b & $<1$ & $<1$ & 4 & _ & _ & - \\
\hline Ferulic acid $b$ & $<1$ & $<1$ & $i$ & 37 & - & - \\
\hline Caffeic acid $b$ & 2 & 2 & 3 & - & 4 & 2 \\
\hline 3-Methyl-3-butenyl ferwlate $b$ & $<\overline{1}$ & $<\overline{1}$ & - & _- & - & - \\
\hline Pentenyl ferulate a & $t$ & - & _- & _ & - & - \\
\hline 3-Methyl-2-butenyl ferulate ${ }^{b}$ & 1 & 1 & - & - & - & - \\
\hline Benzyl ferulate $b$ & - & - & - & 5 & - & - \\
\hline Ethyl caffeate a & - & - & - & - & - & $<1$ \\
\hline Butenyl caffeate a & _- & - & - & _- & $<1$ & $<1$ \\
\hline Butyl caffeate a & - & - & - & - & $<1$ & - \\
\hline Pentyl caffeate a & - & - & - & - & 2 & $<1$ \\
\hline Pentenyl caffeate a & - & - & 4 & - & - & $t$ \\
\hline Pentenyl caffeate (isomer) a & - & - & 6 & - & - & - \\
\hline 3-Methyl-3-butenyl caffeate b & 5 & 4 & 17 & - & 4 & 3 \\
\hline Pentenyl caffeate (isomer) a & 2 & 2 & 3 & - & - & - \\
\hline 3-Methyl-2-butenyl caffeate b & 6 & 5 & 22 & - & 27 & 24 \\
\hline Benzyl caffeate a & 3 & 1 & $<1$ & - & - & - \\
\hline$\beta$-Phenylethyl caffeate a & 7 & 6 & 12 & - & 1 & 2 \\
\hline \multicolumn{7}{|l|}{ Other acids } \\
\hline Benzoic acid b & _ & _- & t & 1 & - & _ \\
\hline Miristic acid b & $t$ & - & - & - & - & - \\
\hline Palmitic acid b & $<1$ & - & - & _ & - & - \\
\hline Stearic acid b & $t$ & - & - & - & - & - \\
\hline \multicolumn{7}{|l|}{ Acetophenone derivatives } \\
\hline Dihydroxyacetophenone a & $t$ & - & - & - & - & - \\
\hline Dihydroxymethoxyacetophenone a & $i$ & $t$ & $\mathrm{t}$ & - & - & - \\
\hline \multicolumn{7}{|l|}{ Unknown components } \\
\hline$x-1$ & - & - & - & - & 4 & 3 \\
\hline$x-2$ & - & - & - & - & 2 & 1 \\
\hline$x-3$ & 3 & 2 & $<1$ & - & - & - \\
\hline$x-4$ & 2 & 2 & 2 & - & - & - \\
\hline$X-5$ & 2 & 2 & 3 & - & - & _ \\
\hline$x-6$ & 2 & 2 & - & - & _- & _ \\
\hline$x-7$ & 4 & 5 & _ & - & _ & _ \\
\hline$x-8$ & 2 & 3 & 1 & - & - & _- \\
\hline
\end{tabular}

$\mathrm{t}:$ traces; $<1$ : less than $1 \% . \mathrm{X}-1$ to $\mathrm{X}-8$ : unidentified components. a: identification on the basis of mass-spectral characteristics. We have not confirmed our identification by comparison with an authentic reference standard, as we do not have one. b: identification on the basis of comparison with an authentic reference standard. 
excelsior, Salix alba, Prunus padus and Prunus cerasus, as well as propolis were collected in the Sofia region. In Mongolia propolis and buds from Populus suaveolens were collected in the region of Ulan Bator, poplars $P$ suaveolens being the only trees in this area. The bud secretions (after a brief extraction with acetone) were analysed by TLC and HPLC. Phenolics similar to those of Bulgarian propolis were found only in bud secretions from Populus nigra, $P$ italica and $P$ tremula, so they were further investigated using GC/MS. The other tree bud secretions were not analyzed by GC/MS, since they did not contain the main propolis phenolic constituents. The preliminary investigation of Mongolian propolis and $P$ suaveolens bud secretions showed a similarity in their phenolics, so both extracts were also analyzed by GC/MS. The results obtained are summarized in table $\mathrm{I}$.

\section{Bulgarian propolis and poplar buds}

It is evident from table I that composition of phenolic constituents of $P$ nigra bud secretions is extremely similar to that of propolis from the same region. Only some minor phenolic constituents, as well as fatty acids are absent. In Bulgarian propolis and $P$ nigra bud secretions we found phenolic acids, flavonoids and a series of phenolic acid esters: caffeates and ferulates. Phenolic fraction from $P$ italica bud secretions contained more phenolic acids and their esters, and fewer flavonoids than $P$ nigra bud secretions. The concentration of isoferulic and caffeic acids in $P$ italica bud secretions are similar, but only caffeic acid esters are present. In $P$ tremula bud secretions the number of flavonoid aglycones was low, these results being in agreement with earlier observations (Popravko and Sokolov, 1980). The phenolic composition of $P$ tremula bud secretions is very differ- ent from that of $P$ nigra and $P$ italica; the main component appears to be ferulic acid. Esters were found in traces and we succeeded in the identification of benzyl ferulate only.

\section{Mongolian propolis and poplar buds}

To our knowledge this is the first investigation of propolis from Mongolia. Phenolic fraction from Mongolian propolis (table I) contained compounds similar to those found in Bulgarian and other kinds of European propolis: phenolic acids and their esters, as well as flavonoid aglycones. Its composition is very close to that of $P$ suaveolens bud secretions. The only phenolic acid in both extracts was caffeic acid, and only caffeates but not esters of other substituted cinnamic acids were found.

\section{DISCUSSION}

It is evident from the results obtained in this study that the phenolic composition of Bulgarian propolis is very similar to that of $P$ nigra bud secretions. We found $31 \mathrm{com}-$ pounds in propolis and 26 of these were found in $P$ nigra bud secretions in similar concentrations. The absence of some minor propolis constituents in $P$ nigra bud secretions could be an indication of the existence of some other minor sources of propolis. The identification of some rare natural compounds (isopentenyl caffeates and ferulates, pinobanksin-3-O-acetate) in Bulgarian propolis and $P$ nigra bud secretions is an additional indication that these bud secretions are the main source of Bulgarian propolis.

In Bulgarian propolis we found 21 phenolic compounds of the 24 found in $P$ italica bud secretions. According to the results shown in table I, $P$ italica bud secretions 
could also be a source of propolis, but to a lesser extent than $P$ nigra bud secretions.

The differences in the phenolic composition of propolis and $P$ tremula bud secretions is more significant; obviously $P$ tremula bud secretions are of very limited importance for propolis.

We can explain the small differences observed in the propolis composition from different regions in Bulgaria (Bankova, Kuleva, 1989) with the participation of different poplar species in it. We do not know why the bees prefer $P$ nigra bud secretions: because this is the most widespread poplar in Bulgaria (Velchev, 1966) or for some other reason; but it is evident that they prefer collecting propolis from $P$ nigra bud secretions.

Instead of seasonal variation of propolis we investigated seasonal variations in phenolic constituents of $P$ nigra bud secretions.

The samples were collected every 3 months and no significant differences in their phenolic composition was found. The phenolic composition of Mongolian propolis is very similar to this of $P$ suaveolens bud secretions. In these bud secretions we found all the compounds of the corresponding propolis in similar concentrations. $P$ suaveolens bud secretions contain more esters than $P$ nigra bud secretions and they are caffeates only. In $P$ suaveolens and Mongolian propolis we did not even find traces of phenolic acids other than caffeic acid. Caffecic acid and caffeates are very important antibacterial constituents of propolis (Ghisalberti, 1979). This is in agreement with our earlier observations that antibacterial activity of Mongolian propolis is higher than that of Bulgarian propolis (Bankova et al, 1989). It is evident that under different ecological conditions: in desert regions (Sonoran Desert, Mexico (Wollenweber et al, 1987)), in the Mongolian midlands, and in the Balkan Peninsula, Populus species are one of the most important sources of propolis and they are of great ecological importance to bees. These conclusions are based on the compounds soluble in organic solvents, these compounds are responsible for the main part of the biological activity of propolis (Ghisalberti, 1979).

\section{ACKNOWLEDGMENTS}

This project has been completed with the financial support of the Ministry of Science and Higher Education (Bulgaria) under contract No 346 . The authors wish to thank N Mollova for GC/MS analysis of $P$ tremula bud secretions.

\section{Résumé - Propolis produite en Bulga-} rie et en Mongolie : composés phénoliques et origine botanique. Des bourgeons de Populus nigra, $P$ italica, $P$ tremula, Betula verrucosa, Aesculus hippocastanum, Alnus glutinosa, Fraxinus excelsior, Salix alba, Prunus padus et Prunus cerasus ainsi que des échantillons de propolis ont été prélevés dans la région de Sofia, Bulgarie. En Mongolie, de la propolis et des bourgeons de Populus suaveolens ont été récoltés dans la région d'Ulan Bator, les peupliers de cette espèce étant les seuls arbres à pousser dans cette région. Les sécrétions des bourgeons, après une brève extraction à l'acétone, ont été analysés en chromatographie sur couche mince et chromatographie liquide haute pression. Seules les sécrétions de bourgeons de Populus nigra, $P$ italica et $P$ tremula ont fourni des phénols semblables à ceux trouvés dans la propolis bulgare. Aussi ont-elles été étudiées en chromatographie gazeuse/spectrométrie de masse. Les résultats obtenus sont présentés dans le tableau I. II est clair que les composés phénoliques des sécrétions de bourgeons de $P$ nigra ressemblent énormément à ceux de la propolis de la même région. La 
fraction phénolique de la propolis mongole (tableau I) contient des composés similaires à ceux trouvés dans la propolis bulgare et dans celles provenant d'autres régions européennes : acides phénoliques et leurs esters aussi bien que les aglycones-flavonoïdes. Sa composition est très proche de celle des sécrétions de bourgeons de $P$ suaveolens. Ceci prouve que dans des conditions écologiques variées, régions désertiques du Mexique (Désert Sonoran, Wollenberger et al, 1987), régions centrales de Mongolie et péninsule balkanique, les espèces de Populus constituent l'une des sources les plus importantes de propolis et qu'elles sont d'une grande importance écologique pour les abeilles. Ces conclusions reposent sur l'analyse de composés solubles dans des solvants organiques et responsables en grande partie de l'activité biologique de la propolis (Ghisalberti, 1979).

propolis / bourgeon / Populus / phénol / GC/MS

\section{Zusammenfassung - Propolis aus Bul- garien und aus der Mongolei: Phenol- verbindungen und pflanzliche Herkunft.} In Bulgarien wurden Knospen von Populus nigra, $P$ italica, $P$ tremula, Betula verrucosa, Aesculus hippocastanum, Alnus glutinosa, Fraxinus excelsior, Salix alba, Prunus padus und Prunus cerasus gesammelt, sowie auch Propolis aus der Region von Sofia. In der Mongolei wurden in der Region von Ulan Bator Propolis sowie auch Knospen von Populus suaveolens (dem einzigen Baum dieser Region) gesammelt. Die Knospensekrete wurden nach kurzer Extraktion mit Aceton mittels TLC und HPLC analysiert. Ähnliche Phenole wie in der bulgarischen Propolis wurden nur in den Knospensekreten von Populus nigra, $P$ italica und $P$ tremula gefunden. Deshalb wurden diese mittels $G C /$
MS weiter analysiert. Die erzielten Resultate sind in Tabelle I zusammengefaßt. Aus dieser Tabelle wird deutlich, daß die $\mathrm{Zu}$ sammensetzung der Phenolbestandteile von den Knospensekreten von $P$ nigra derjenigen der Propolis aus derselben Region extrem ähnlich ist. Die Phenolfraktionen der mongolischen Propolis (Tabelle I) enthielten Verbindungen, die den in bulgarischer Propolis so wie an, europäischer Herkunft sehr ähnlich sind: Phenolsäuren und ihre Ester, so wie Flavon-Aglykone. Ihre Zusammensetzung ist sehr ähnlich wie die der Knospensekretion von $P$ suaveolens. Es ist klar, daß unter den verschiedenen ökologischen Verhältnissen von Wüstenregionen (Sonora Wüste, Mexiko (Wollenweber et al, 1987)), im mongolischen Mittelland und am Balkan Pappelarten zu den wichtigsten Propolisquellen gehören und für die Bienen von großer ökologischer Bedeutung sind. Diese Schlußfolgerungen beruhen auf den in organischen Mitteln lösbaren Verbindungen, die auch für den Hauptteil der biologischen Aktivität von Propolis verantwortlich sind (Ghisalberti, 1979).

\section{Propolis / Knospe / Populus / Phenol / GC/MS}

\section{REFERENCES}

Bankova V, Kuleva L (1989) Phenolic compounds in propolis from different regions of Bulgaria. Shivotnovadni nauki 2, 94-98 (in Bulgarian)

Bankova V, Popov S, Marekov N (1982) High performance liquid chromatographic analysis of flavonoids from propolis. $J$ Chromatogr 242, 135-143

Bankova $V$, Kujumgiev A, Ignatova A, Dyulgerov A, Pureb O, Zamjansan Z (1989) Antibacterial activity of Bulgarian and Mongolian propolis and poplar buds. Proc Vth int Conf Chem Biotechnol Biol Active Nat Prod Sept 18-23 1989, Varna, Bulgaria, vol 2, 239-243 
Ghisalberti E (1979) Propolis: a review. Bee World 60 (2), 59-84

Greenaway W, Scaysbrook T, Whatley FR (1987) The analysis of bud exudate of Populus $x$ euramericana, and of propolis, by gas chromatography-mass spectrometry. Proc $R$ Soc Lond B 232, 249-272

Ivanov $Z$ (1987) A study on some components and physical and chemical properties of propolis and bees wax. Shivotnovadni Nauki (4), 84-88

Koenig B (1985) Plant sources of propolis. Bee World 66 (4), 136-139

Lavie $P$ (1976) The relation between propolis, poplar buds (Populus spp) and castoreum. Proc XXV Int Beekeeping Congr (Grenoble 1975). Apimondia Publ, Bucharest, 227-231

Lejeune B, Vennat $B$, Regerat $F$, Gardelle $D$, Foucher D, Pourrat A (1984) Propolis extraction and utilisation in shampoos and lotions. Parf Cosm Aromes 56, 65-68
Papay V, Toth L, Soltes M, Nagy E, Litkei G (1986) isolated compounds from Hungarian propolis and populi gemma. Stud Org Chem (Amst) 23, 233-240

Pochinkova P (1986) Pchelnite Produkti v Medizinata. Sofia, BAN Publ, 56-86

Popravko AS (1976) Vegetable sources of propolis. Pchelovodstvo (7), 38-39 (in Russian)

Popravko AS, Sokolov IV (1980) Plant sources of propolis. Pchelovodstvo (2), 28-29 (in Russian)

Velchev V (1966) Flora of PR Bulgaria, BAS PUbl House, Sofia. vol 3, 39-48

Walker P, Crane E (1987) Constituents of propolis. Apidologie 18, 327-334

Wollenweber E, Asakawa Y, Schillo D, Lehmann $U$, Weidel $H$ (1987) A novel caffeic acid derivative and other constituents of Populus bud excretion and propolis (bee-glue). $Z$ Naturforsch 42c, 1030-1034 